\title{
Investigation of smart growth in traditional Islamic culture: Case study of Isfahan city in Iran
}

\author{
Ali Assari ${ }^{1 *}$, Shahead Maghreby ${ }^{2}$ and Maryam Mousavi Nik ${ }^{3}$ \\ ${ }^{1}$ Department of Art and Architecture, Payame Noor University of Iran, Iran. \\ ${ }^{2}$ Urban Design Department, Architecture and Urban Design School, Art University of Isfahan, Iran. \\ ${ }^{3}$ Mental Health Research Center, Tehran Institute of Psychiatry, School of Behavioral Sciences and Mental Health, \\ University of Medical Sciences, Tehran, Iran.
}

Received 19 October, 2016; Accepted 2 December, 2016

\begin{abstract}
There is widespread urban growth in a new concept with sustainable development in each society; it includes type of housing, mix land use, socio-cultural support and public transit access. This study firstly focuses on analyzing the land use pattern, transportation and cultural accessibility as well as investigating their relationship of smart growth in municipalities' districts of Isfahan city. Secondly, it develops a framework of historical Iranian cities which aims to evaluate the use of smart growth principles in traditional Islamic culture. The study made use of descriptive-analytic by using secondary data and urban development plan documents. The research population includes 14 regions of Isfahan which is based on political divisions in 2012. The research indicators can be divided into ten groups of social-economic-environment which aims to investigate smart growth principles in Isfahan city. The study used Technique for Order Preference by Similarity to Ideal Solution method (TOPSIS) to identify the most strategic elements of smart growth in Isfahan municipality districts, which are consider to minimize low density sprawl.
\end{abstract}

Key words: Municipality district, smart growth, TOPSIS, Iranian cities, urban sprawl.

\section{INTRODUCTION}

In recent decades, urban population increase dramatically, United Nations estimates, the population living in urban areas exceeded $50 \%$ of the world total in 2006 and will approach $60 \%$ in 2020 and Urban population in Iran will reach 80\% in 2020 (Stalker, 2000; Saeed, 2011). The proportion of urban population to total population of Iran in 1976 was $47 \%$ and this ratio reached $68 \%$ in 2006 (Fanni, 2006; Ferdowsian, 2001; Statistical centre of Iran,
2006).

According to Ministry of Housing and Urban Development (Ministry of Housing and Urban Development, 2008) cities in Iran are divided into six categories: rural urban cities (population less than 25,000); small cities (population between 25,000 and 100,000); medium cities (population between 100,000 and 500,000); large cities (population between 500,000 and 1,000,000);

*Corresponding author. E-mail: ali_assari1358@yahoo.com.

Author agree that this article remain permanently open access under the terms of the Creative Commons Attribution License 4.0 International License 
metropolis (population between 1 million and 5 million); and, Finlay, megalopolis (population more than 5 million). Therefore, Isfahan can be considered as a metropolis sized city (Iranian Statistic Center, 2009). Solutions for Isfahan Rapid Urbanization presents a set of principles and policies collectively referred to as "smart growth" that is an American model of urban sprawl (Leichenko and Solecki, 2005)

Miller and Hoel believes the Smart growth, including the adoption of mechanisms which through efficient use of land and transportation planning seeks to minimize the effects of urban carpet (Miller and Hoel, 2002) and it is considered as an alternative option for curbing urban carpet. Smart growth is based on approach to develop the metropolitan areas, which serves the economy, society and environment (Price and Benton-Short, 2008). Smart growth is a pattern, which insists on the utilization of land and existing buildings, preservation of historic buildings and residential units and local character of the community to enhance the sense of belonging to a place and protection of the environment for the future generations (Bhatta et al., 2010), and it is one of the urban planning theories, which seeks intensive land uses, transit-oriented and it loves walking and cycling and development based on the combined uses (Brueckner, 2000). Hasse (2004) believes that, following the pattern of urban growth of the principles of smart growth reduces environmental impacts and social costs of development of distributed species. High density and compact land use patterns, by encouraging and improving the lifestyles based on walking will improve quality of life and successful implementation of smart growth policies needs to accept the policies that are inconsistent with the pattern of low-density living (Haase and Nuissl, 2007).

Urban sprawl has become a remarkable characteristic of urban development worldwide in the last decades. Urban sprawl refers to the extent of urbanization, which is a global phenomenon mainly driven by population growth and large scale migration (Jamal, 2012). During the past 30 years, Isfahan has also experienced an enormous population boom, due to both natural increase and rural to urban migration. These transformations have both changed people's life style and created a series of environmental and socioeconomic issues associated with urban development. Unmanaged city growth, a shortage of affordable housing, high unemployment rates, high crime rates, heavy traffic, air pollution and environmental degradation, health problems are some of the major issues that Isfahan face today (Alavi, 2012).

The purpose of this research is to study the smart growth concept and effective factors on them in fourteen municipality districts of Isfahan city in Iran. Isfahan city is still at rapid urbanization phase, thus urban sprawl is their common problem, so smart growth concept might be applicable in reducing the problem (Mirmoghtadaee, 2010). This rapid urbanization in Isfahan threatens to produce shortages of land resources, damage to the environment, and social inequity.

\section{Smart growth in historical cities}

"Smart growth" is a relatively recent planning paradigm which has emerged largely in response to the patterns of urban and suburban development described by Jacobs nearly three decades ago (Jacobs, 1961). Smart growth joins the ranks of the new urbanism, nontraditional planning, livable communities, sustainable development, and other modern planning theories that attempt to plan and develop communities that will more successfully serve the needs of those who live and work in them (Smart Growth, 2003 case study: Western Reverside County, 2003).

In other words smart growth invests time, attention, and resources in restoring community and vitality to center cities and older suburbs and in encouraging more towncentered and transit- and pedestrian-oriented new development (Kemp, 2001: 73). According to Cowan (2005), the following 10 principles of smart growth identified by the US Environmental Protection Agency are presented in Figure 1.

Smart growth is meant to describe development strategies that do not promote urban sprawl (Gabriel et al., 2006). And it has been widely adopted to characterize compact patterns of development that do not symbolize the negative characteristics of sprawl (Batisani and Yarnal, 2011; Danielsen, 1999; Hasse, 2004; Iran, 2012). However, the term is somewhat open to interpretation. The multi objective aspects arise when considering the conflicting interests of the various stakeholders involved in land development decisions. The main advocates of the smart growth principles in historical city of Isfahan is: less car dependency, low emissions, reduced energy consumption, better public transport, increased overall accessibility, re-use of the Infrastructure and of previously developed land, rejuvenation of the existing urban areas and urban vitality, high quality of life, preservation of green space (Figure 4), and a milieu for enhanced business and trading activities (de Sousa, 2008). Therefore, smart growth land use planning seeks to balance the infrastructure needs of a growing human population and protection for the environment (Underwooda et al., 2011)

\section{Study area}

Isfahan is located in $32^{\circ} 38^{\prime} 30^{\prime \prime} \mathrm{N}$ latitude and $51^{\circ} 38^{\prime} 40^{\prime \prime}$ E longitude, about $340 \mathrm{~km}$ south of Tehran and capital of Isfahan Province. Isfahan is the third largest city in Iran after Tehran and Mashhad (Vadiati and Kashkooli, 2011) with numerous historical sites and heritages that are mostly from the Islamic period (Hooshangi, 2000). The minimum height is $1550 \mathrm{~m}$ around Zayandeh Rood and 


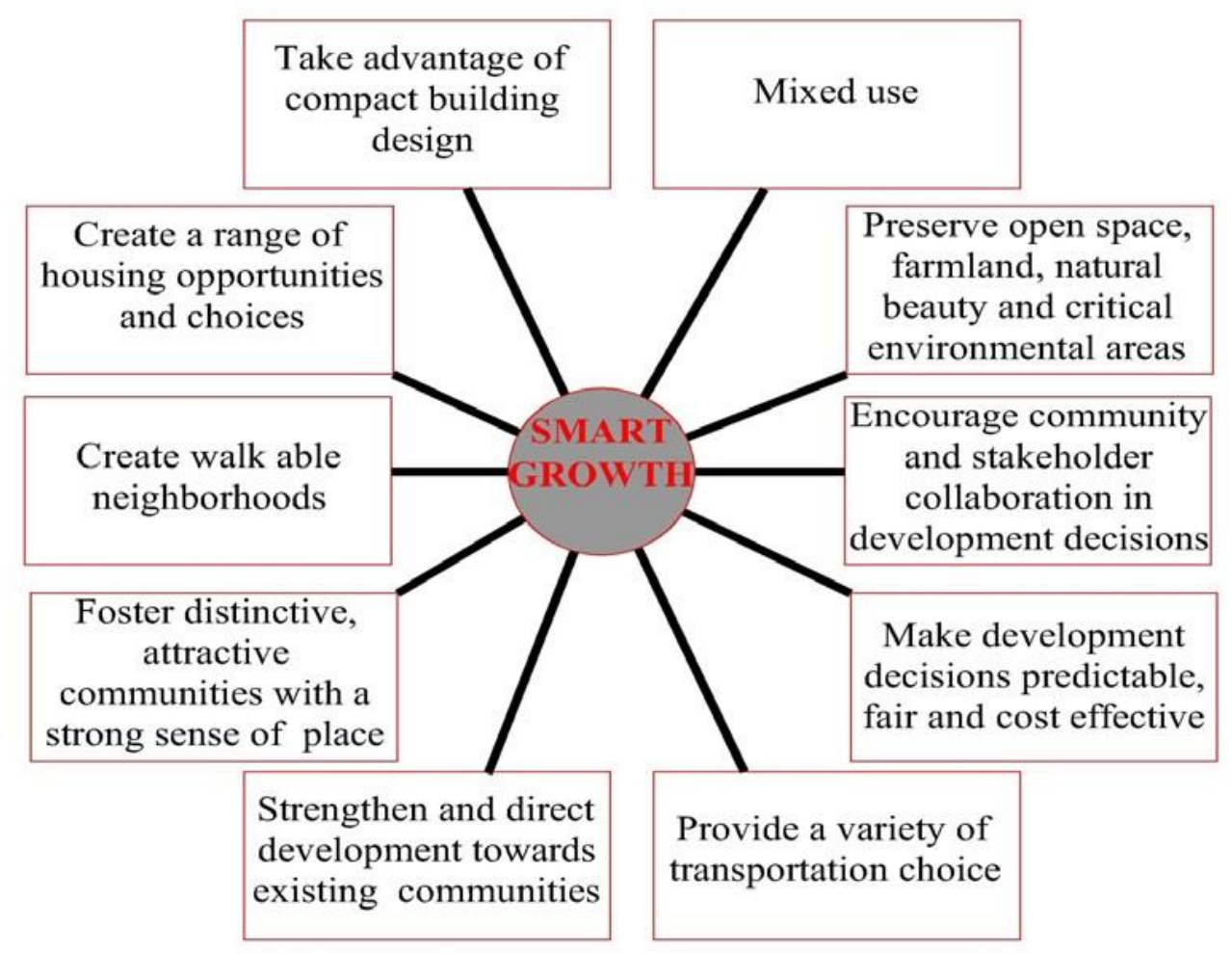

Figure 1. Principles of smart growth.

maximum is $2232 \mathrm{~m}$ in Sofeh Mountains. Annual average precipitation and temperature is $121.1 \mathrm{~mm}$ and $16.2^{\circ} \mathrm{C}$, respectively (Assari and Mahesh, 2011). City of Isfahan had a population of $1,583,609$ and the Isfahan metropolitan area had a population of $3,430,353$ in the 2006 Census, the second most populous metropolitan area in Iran after Tehran. In recent decades, it has been the center of attention and high density of population because of concentration of economic activities like industries, tourism and also demands for cultural development which caused different types of industries, housing, transport, business, cultural, educational and entertain-ment uses (Soffianian et al., 2010).

\section{METHODOLOGY}

The research made us of a descriptive-analytical and co relational study. The required data have been collected through the use of questionnaires from the expert faculty of municipality of Isfahan city, the descriptive results of the 2006 census of population and housing, the Isfahan detailed plan and master plan, as well as the use of journals, documents and the related books. The indexes investigated in this study comprise socio-economic, cultural, physical, and environmental issues as well as issues relating to accessibility and urban equipment and facilities (Ali et al., 2012). For analyzing data in different municipality districts, Technique for Order Preference by Similarity to Ideal Solution method was use (TOPSIS). Statistical program for social sciences
(SPSS) and EXCEL programs have been employed for data analysis. TOPSIS model is one of the best multi-index decisionmaking models. This model is based upon the idea that the selected choice must have the least distance from the ideal positive solution and the most distance from the ideal negative solution (the worst possible situation). The TOPSIS grade ranges from 0 to 1 . The closer the index is to 1 , the more ideal it's the rank. The research population includes 14 regions of Isfahan which is based on political divisions in 2012. The research indicators can be divided into ten groups of social-economic-environment to investigate smart growth principles in Isfahan city.

1. Passage

2. Public parking

3. Household waste collection

4. Old texture

5. Green area (Figure 4)

6. Size of house less than 80

7. Size of house more than 300

8. Density of the area

9. Number of mosques.

The accumulation of aforementioned indicators makes a smart growth composite index.

\section{Land use}

Recently, many historical cities with Islamic traditional culture have undertaken initiatives to implement new land use planning practices so that a balance is reached between infrastructure and conservation of cultural heritage. Iranian historical cities land use planning depends on four major elements which are: 

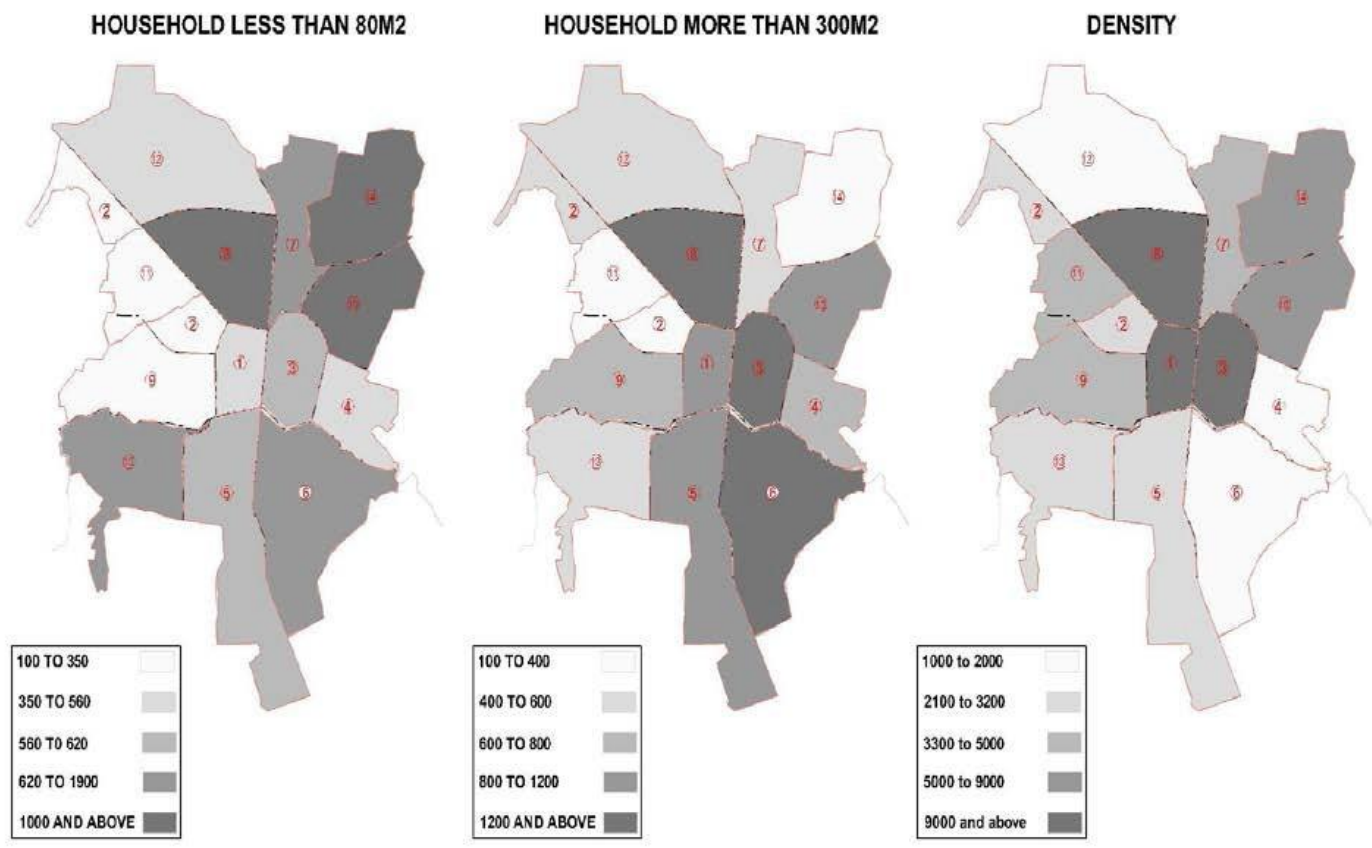

Figure 2. Isfahan municipality district by density an size of household.

1. The great mosque

2. Bazaar

3. Citadel

4. Residential quarters (Ehlers, 1991; Kheirabadi, 2000)

The city core of Isfahan consists of $842 \pm$ acres of land generally divided into 25 categories of land use and located in 3rd municipality district. The majority of the city's land, 303 acres or $36 \%$, is devoted to its residential neighborhoods. Land under transportation use is 182 acres which constitutes $21.6 \%$ of total land use and commercial, and bazaar is under 107 acres or $12.7 \%$, which is next to largest categories of land use.

Public and semipublic, garden and park and open space comprises of $4.3,4.2$ and $3.7 \%$ respectively. In category of public and semipublic administration, disciplinary with $4.3 \%$ and cultural with $3.4 \%$ got the highest rank in land use planning. Industrial uses under 15 acres constituting $1.8 \%$ land in the core area of the city. Building with more than 30 years old got the highest rank which is $62.8 \%$ in age structure of Isfahan city core and $61 \%$ of the structure is of good quality (Ali et al., 2012). In other words, reconstruction and renovation of this part of the city should be the main concern of the local authorities. Modernization in Isfahan has led to many social, cultural, and physical transformations. However, modernization is concentrated on the physical aspects of life, leaving unchanged most of the cultural norms and values that constitute living habits. This new type of residence introduced modern facilities for more comfortable living, but departed greatly from the familiar traditional houses (Assari and Mahesh, 2011).

The highest number of housing unit in the area lies between 100 to 150 square meter which means the regular size of the house stand in this particular category. The 3rd municipality district number of the houses in last category (500 m2 and more) stands in the highest rank compare to other district. And also in Figure 2, the heritage textures are in highest density, this unbalance share shows that in heritage texture of Isfahan city traditional house play an important role in Housing form of Isfahan city (Figure 2).

\section{Traffic and transportation}

In Isfahan regarding growth and spread of urbanization, urban migration, weakness and lack of urban services, the urban problems are more complex than ever and urban land use planning has been faced with serious challenges. Among the urban land use, parking land use is important to the users because all urban users need it and it is clear that in a world dependent on car, parking as well as roads and bridges are important, because easy access to work, residence, shopping and entertainment are made possible with them (Farzanmanesha et al., 2010).

Therefore it is an integral part of the infrastructure sector. Since the time of car stops in cities is much longer than their departure time, therefore predicting the suitable space for parking cars, especially in crowded areas and downtown is very important. But despite all the organizational planning for parking in the city of Isfahan and the great help and assistance of city managers, parking user condition in the present situation is very worrying and it can be mentioned as a complex urban problem. On the other hand, volume of vehicle entry to the city of Isfahan, the ease of car buying and ownership interest of citizens to use personal vehicles for various reasons and the increase of urban travel because of poor access to municipal services, is one of the reasons that signify the importance of parking user (Mokhtari, 2010).The problem facing to the traffic and transportation of heritage areas in Isfahan city categories below are (Assari and Assari, 2012):

1. The historical areas are mostly having narrow roads with many dead-end streets.

2. The vehicles are parked opposite the entrance of heritage monument that has historic value and disturbing the easy movement of pedestrian (Mousavi et al., 2015).

3. Poor level of service affecting safety, efficiency and economy of traffic operation

4. Traffic congestion problems in heritage areas especially in CBD 5. Parking on road reduces the capacity of road networking and making difficult flow of traffic by occupation width of road (Ali et al., 
2015).

6. Irregular movement of pedestrian in Main Street toward the historic area and taxis that carry to inner city do not have any organization in main road.

\section{Cultural facilities and accessibility}

This category represents several of public places such as libraries, community centres and mosque. Libraries can be combined with a number of other facilities like social and cultural facilities. It should be easily accessible, preferably on main thoroughfare convenient to main traffic and transportation routes. Libraries should be within walking distance of the communities they are to serve and it should be within 5 min walking distance of a public transport stop (CSIR, 2000). Mosques in Islamic cities are almost occupied the heart of the towns or any neighborhoods and is usually surrounded by bazaar (Saoud, 2002). The large mosque is called a Jami Masjid, Masjid means "place of prostration" mosques are generally community facilities and should be located within walking distance for members. Maximum walking distance: $1.5 \mathrm{~km}$. All Muslims are required to pray together every Friday at midday and the large mosques were constructed for this purpose (Adamec, 2009).

1. Improved transport options, particularly for non-drivers

2. Increased housing options

3. Community cohesion

4. Cultural resource preservation (historic sites, traditional neighborhoods, etc.)

5. Increased physical exercise and health

Technique for order-preference by similarity to ideal solution (TOPSIS)

TOPSIS is one of the useful Multi Attribute Decision Making techniques, which is very simple and easy to implement, so it is used when the user prefers a simpler weighting approach (Ball and Korukoğlu, 2009). It was firstly proposed by Hwang and Yoon (1981). According to this technique, the best alternative would be the one that is nearest to the positive ideal solution and farthest from the negative ideal solution (Benitez et al., 2007; Asgharpour, 1999).

The positive ideal solution is a solution that maximizes the benefit criteria and minimizes the cost criteria, whereas the negative Ideal solution maximizes the cost criteria and minimizes the benefit criteria. TOPSIS method can be used with both normal numbers and fuzzy numbers. It is a method for ranking the parameters and in this article writers uses it to rank all the affective parameters on role of public participation on sustainable development which were about 18 parameters that collected from people who lives in heritage area in Isfahan city. The method is calculated as follows:

Step 1. Decision matrix is normalized via Eq. (1):

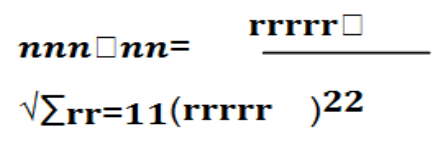

nij: stands for the score of each parameter which has been none scaled.

rij: is stands for utility of each parameter. $\mathbf{i}=$ number of question (1 to 18 )

$\mathbf{j}=$ rank of question (1 to 5 )

Step 2. Weighted normalized decision matrix is formed:

$$
\mathrm{V}=\mathrm{Nd}^{*} \mathrm{~W}_{\mathbf{n}, \mathbf{n}}
$$

V: stands for the none scaled weight matrix

Step 3. Positive ideal solution (PIS) and negative ideal solution (NIS) are determined:

$P I S=A+=\left\{\left(\max V_{i j}\right),\left(\max V_{i j}\right), i, j=1,2, . ., m\right\}=\left\{V_{1}+, V_{2}+, \ldots V_{n+}\right\}$

$N I S=A-=\left\{\left(\min V_{i j}\right),\left(\min V_{i j}\right), i=1,2, . ., m\right\}=\left\{V_{1}-, V_{2}-, \ldots V_{n}-\right\}$

Step 4. The distance of each alternative from PIS and NIS are calculated:

$$
\begin{aligned}
& D D_{-} \quad=\quad \overline{\curvearrowright n n=11 \text { (vvnnn } \square-} \\
& \text { vvrr-)^22 } \\
& D D+=\hat{\vartheta} \sum n n=\overline{11(\text { vvnnn } \square-\operatorname{vvrr}+)^{\wedge} 22}
\end{aligned}
$$

Step 5. The closeness coefficient of each alternative is calculated:

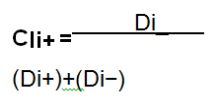

Step 6. By comparing $\mathrm{Cli}$ values, the ranking of alternatives are determined.

The correlation matrix presented in Table 3 shows investigation relationships among the variables. Correlation significant at the 0.05 level shows red color number and at 0.01 level shows red color with red cell (1-tailed). Paying attention to the correlation matrix, by the red colored values we found out that there are some variables with approximately high correlation. For instance there is positive relation between "Garbage collection" and "less than 80 (m2) house" and negative relation between "green area" (Figure 4) and "density of the area" in Table 1 municipality district shows by M.D and ranking of them by TOPSIS method shows in Table 2.

\section{RESULTS AND DISCUSSION}

The study employs regression analysis in order to predict indices influential in smart growth in historical city like Isfahan. The findings of the regression analysis generally indicate that among the 10 indexes of 13th municipality district and from the analysis done for ten different cases above, one may acknowledge few common points which are important to notice (Moghimi and Assari, 2016).

1. The proposed TOPSIS model provides a performance evaluation tool with a unique ranking for each principle of smart growth in all 13th municipality.

2. According to the result presented in Table 3, the house 
Table 1. Data on municipalities district of Isfahan.

\begin{tabular}{|c|c|c|c|c|c|c|c|c|c|}
\hline Variable & $\begin{array}{c}\text { Passage } \\
\left(\mathrm{m}^{2}\right)\end{array}$ & $\begin{array}{c}\text { Public } \\
\text { parking }\left(\mathrm{m}^{2}\right)\end{array}$ & $\begin{array}{c}\text { Household waste } \\
\text { collection (kg per } \\
\text { day) }\end{array}$ & Old texture & Green area & $\begin{array}{c}\text { Size of } \\
\text { house less } \\
\text { than } 80 \\
\end{array}$ & $\begin{array}{c}\text { Size of } \\
\text { house more } \\
\text { than } 300\end{array}$ & $\begin{array}{c}\text { Density of the } \\
\text { area (person per } \\
\text { hectare) }\end{array}$ & $\begin{array}{c}\text { No. of } \\
\text { mosques }\end{array}$ \\
\hline $1 \mathrm{md}$ & $718(2)$ & $28060(4)$ & $62660(3)$ & $223.44(3)$ & $432266(1)$ & $1892313(2)$ & $1172(4)$ & $9240.75(4)$ & $9240.75(4)$ \\
\hline $2 \mathrm{md}$ & $1042(3)$ & $0(1)$ & $28943(4)$ & $88.33(1)$ & 2323920 (3) & $2200092(1)$ & $309(1)$ & $2668(2)$ & $53(3)$ \\
\hline $3 \mathrm{md}$ & $663(2)$ & $53050(4)$ & $88552(2)$ & $313.6(4)$ & 799033 (1) & 2205617 (3) & $1255(4)$ & $10165.09091(4)$ & $188(4)$ \\
\hline $4 \mathrm{md}$ & $774(2)$ & $42235(4)$ & $77966(2)$ & $113.2(2)$ & $9782847(4)$ & $3472502(3)$ & $796(3)$ & $1592.733333(1)$ & $52(3)$ \\
\hline $5 \mathrm{md}$ & $1493(4)$ & $49400(4)$ & $108075(1)$ & $69.75(1)$ & $5579814(4)$ & 3573535 (3) & $1169(4)$ & $2416.05(2)$ & $39(1)$ \\
\hline $6 \mathrm{md}$ & $1399(4)$ & $37850(4)$ & $85635(2)$ & $122.07(2)$ & $3349845(3)$ & $2658274(3)$ & $1292(4)$ & $1634.409091(1)$ & $58(3)$ \\
\hline $7 \mathrm{md}$ & $1589(4)$ & $11900(3)$ & $78458(2)$ & $187.94(3)$ & $3742872(3)$ & $3108419(3)$ & $465(2)$ & $4766.807018(3)$ & $45(2)$ \\
\hline $8 \mathrm{md}$ & $1118(3)$ & $5050(2)$ & $123817(1)$ & 212.07 (3) & $1593594(2)$ & $4581483(4)$ & $1289(4)$ & 10021.31707 (4) & $62(3)$ \\
\hline $9 \mathrm{md}$ & $613(2)$ & $12000(3)$ & $41683(4)$ & $232.67(3)$ & $1035155(1)$ & 1947866 (1) & $604(2)$ & 3554.923077 (2) & $66(3)$ \\
\hline $10 \mathrm{md}$ & $1299(4)$ & $5800(2)$ & $108996(1)$ & $231.55(3)$ & 2211946 (3) & $4226515(4)$ & $840(3)$ & $9046.47619(4)$ & $72(3)$ \\
\hline $11 \mathrm{md}$ & $374(1)$ & $5600(2)$ & $31435(4)$ & $94.25(1)$ & $589750(1)$ & $1344651(1)$ & $244(1)$ & 5113.272727 (3) & $39(1)$ \\
\hline $12 \mathrm{md}$ & $1439(4)$ & $0(1)$ & $62803(3)$ & $111.35(2)$ & $1958461(3)$ & 3829584 (3) & $545(2)$ & $1284.292683(1)$ & $35(1)$ \\
\hline $13 \mathrm{md}$ & 1049 (3) & $3500(2)$ & $65995(3)$ & $76.29(1)$ & $2517773(3)$ & 2347889 (3) & $447(2)$ & $3162.347826(2)$ & $32(1)$ \\
\hline $14 \mathrm{md}$ & $753(2)$ & $2000(2)$ & $73203(2)$ & $80.2(1)$ & $2249126(3)$ & $2700277(4)$ & $131(1)$ & $7343.789474(-4)$ & $53(3)$ \\
\hline
\end{tabular}

Table 2. Ranking of municipality district by TOPSIS method.

\begin{tabular}{llc}
\hline Sort CLi+ & Municipality district & Rank \\
\hline 0.576493 & M.D.3 & 1 \\
0.567828 & M.D.10 & 2 \\
0.560009 & M.D.6 & 3 \\
0.5571 & M.D.5 & 4 \\
0.543166 & M.D.1 & 5 \\
0.536274 & M.D.8 & 6 \\
0.493042 & M.D.4 & 7 \\
0.48889 & M.D.7 & 8 \\
0.449401 & M.D.14 & 9 \\
0.397679 & M.D.12 & 10 \\
0.379352 & M.D.2 & 11 \\
0.378347 & M.D.9 & 12 \\
0.355662 & M.D.13 & 13 \\
0.310591 & M.D.11 & 14 \\
\hline
\end{tabular}


Table 3. Correlation matrix.

\begin{tabular}{|c|c|c|c|c|c|c|c|c|c|c|}
\hline Variable & $\begin{array}{c}\text { Passage } \\
\text { (m2) }\end{array}$ & $\begin{array}{l}\text { Public } \\
\text { parking } \\
(\mathrm{m} 2)\end{array}$ & $\begin{array}{c}\text { Garbage } \\
\text { collection (kg } \\
\text { per day) }\end{array}$ & $\begin{array}{c}\text { Old } \\
\text { texture }\end{array}$ & $\begin{array}{c}\text { Green } \\
\text { area }\end{array}$ & $\begin{array}{l}\text { Less than } \\
80(\mathrm{~m} 2) \\
\text { house }\end{array}$ & $\begin{array}{c}\text { More than } \\
300(\mathrm{~m} 2) \\
\text { house }\end{array}$ & $\begin{array}{c}\text { Density } \\
\text { of the area (person } \\
\text { per hectare) }\end{array}$ & $\begin{array}{c}\text { No of } \\
\text { mosques }\end{array}$ & $\begin{array}{l}\text { Libraries and } \\
\text { cultural } \\
\text { centers }\end{array}$ \\
\hline passage $\left(m^{2}\right)$ & 1 & -0.010 & 0.497 & -0.179 & 0.281 & 0.651 & 0.216 & -0.306 & -0.332 & 0.236 \\
\hline public parking $\left(\mathrm{m}^{2}\right)$ & -0.010 & 1 & 0.355 & 0.236 & 0.426 & -0.046 & 0.695 & -0.018 & 0.510 & 0.516 \\
\hline Garbage collection (kg per day) & 0.497 & 0.355 & 1 & 0.280 & 0.260 & 0.785 & 0.671 & 0.387 & 0.199 & 0.351 \\
\hline old texture & -0.179 & .236 & 0.280 & 1 & -.397 & 0.038 & .498 & .694 & 0.779 & 0.514 \\
\hline green area & 0.281 & .426 & 0.260 & -0.397 & 1 & 0.385 & .074 & -.523 & -0.296 & 0.216 \\
\hline less than $80(\mathrm{~m} 2)$ house & 0.651 & -0.046 & 0.785 & 0.038 & 0.385 & 1 & .327 & 0.072 & -0.173 & 0.152 \\
\hline more than $300(\mathrm{~m} 2)$ house & 0.216 & 0.695 & 0.671 & 0.498 & 0.074 & .327 & 1 & 0.303 & 0.472 & 0.654 \\
\hline Density of the area (person per hectare) & -0.306 & -0.018 & 0.387 & 0.694 & -0.523 & .072 & 0.303 & 1 & 0.605 & 0.059 \\
\hline No of Mosques & -0.332 & 0.510 & 0.199 & 0.779 & -0.296 & -.173 & 0.472 & 0.605 & 1 & 0.402 \\
\hline libraries and cultural centers & 0.236 & 0.516 & 0.351 & 0.514 & 0.216 & .152 & 0.654 & 0.059 & .402 & 1 \\
\hline
\end{tabular}

with less than 80 meter has the most correlation with Garbage collection (kg per day) and number of mosque in old texture got the second high rank in correlation

3. The less than 80 (m2) house, garbage collection (kg per day), density of the area (person per hectare) and number of mosques have the greatest impact on the smart growth in Isfahan city of the 4 municipality districts $(3,10,6,5)$.

4. The best municipality in Isfahan city according to TOPSIS method was 3rd municipality district with $\mathbf{C L i}+(0.576493)$ for the year 2012.

5 . And the worst one was 11 th municipality district with $\mathbf{C L i}+(0,232)$

6. In each of municipalities discussed above, it is observed that almost the results are consistent with significant amount of association/correlation between the ranks obtained by the TOPSIS model.

7. The findings resulting from the ranking of districts indicates inequality and difference in some indexes shows that The greatest rank is seen in heigest density and the smallest inequality is seen from the lowest density (fig 2)

\section{CONCLUSION}

Smart growth or quality growth in historical Islamic cities like Isfahan are seen as a possible solution when cities are faced with issues such as sprawl cleaning, traffic and accessories to main social and cultural requirement. City core development in Isfahan can be divided into two categories: those that are already developed centers and those that are planned for development. They are characterized by a defined central core of Iranian city such as bazaar, residential quarter, citadel and jame mosque (Ehlers and Floor, 1993)

This provides many of the functions needed by the requirement of residents and culture of society and sense of place. The most important issue in historical texture is rehabilitation of older buildings and neighborhoods in heart of the city (3rd municipality district). This issue plays a critical role in advancing "smart growth" objectives
(Cervero, 2004), except Buffer Zone (Figure 5), with the aim of protecting the world heritage sites such as Naghsh-e- Jahan square (1979) and Masjed-e Jame (2012) which is becoming an issue of concern.

Regarding (Figure 6) the number of high rise building which reduces throughout these two monuments and in Isfahan CBD, it is difficult to place a large buffer zone around a heritage sites to make sure there is sufficient protection. Development plans and smart growth principles in existing CBD including Chaharbagh street, bazaar, and all heritage area in heart of the city promote "in-fill" development (Farris, 2001) is compatible with traditional historical cities in Iran , and encourage on e to absorb the population in heritage and old texture of Isfahan city. Figure 3 defines the distribution of heritage area in whole of Isfahan city.

\section{Conflict of Interests}

The authors have not declared any conflict of interests. 


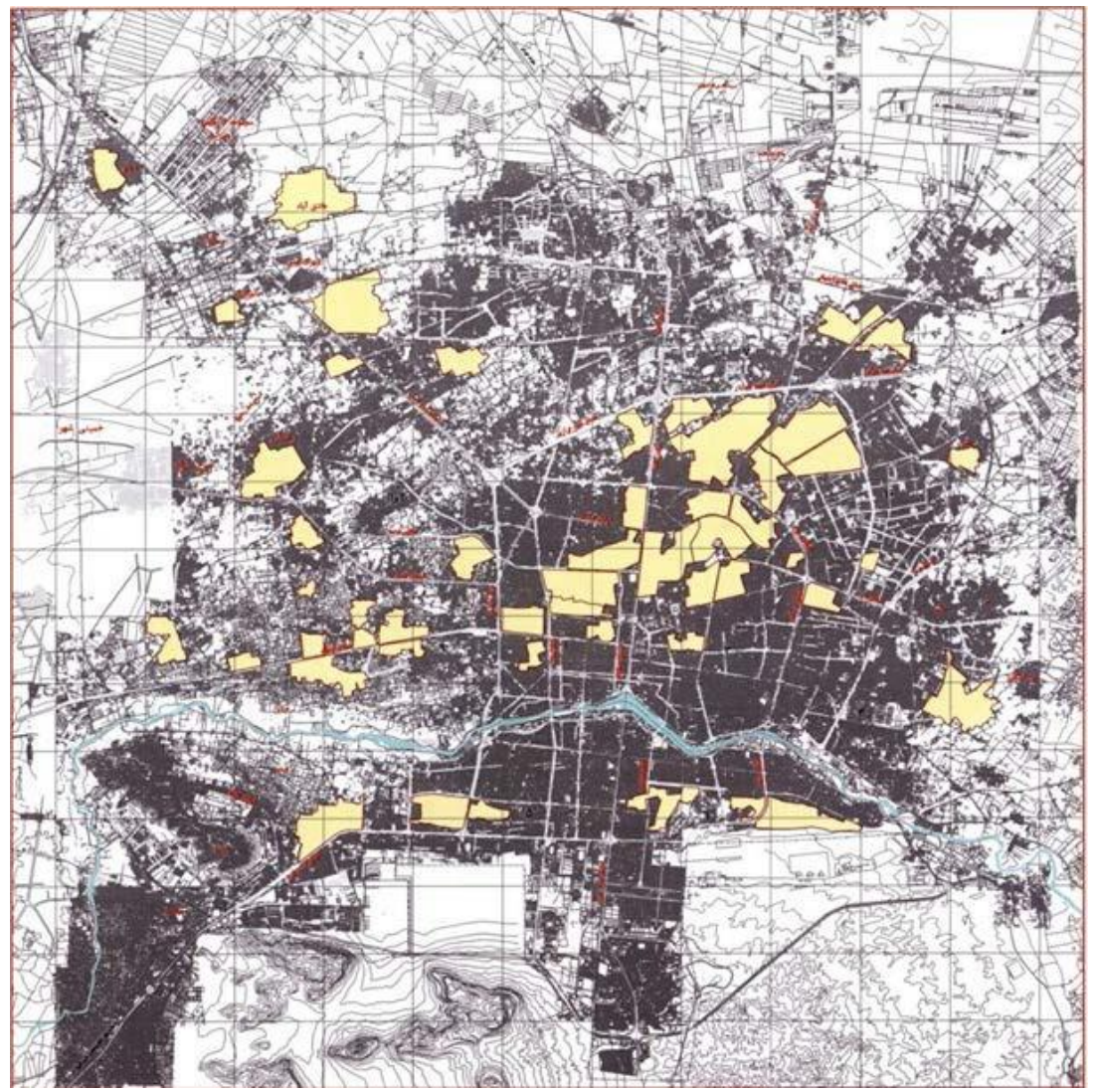

Figure 3. Distribution of old and heritage texture in Isfahan city.

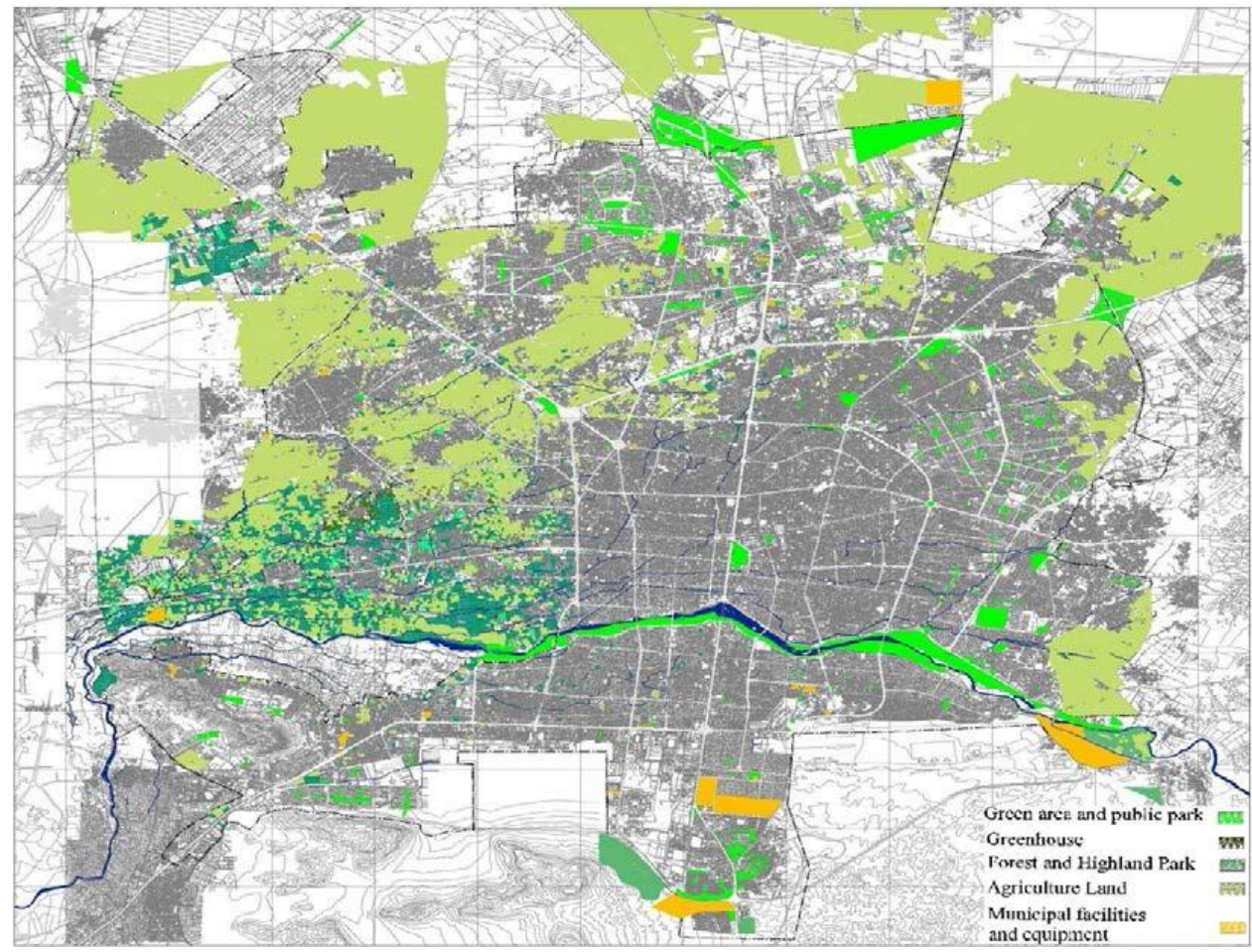

Figure 4. Distribution of green area in Isfahan city. 

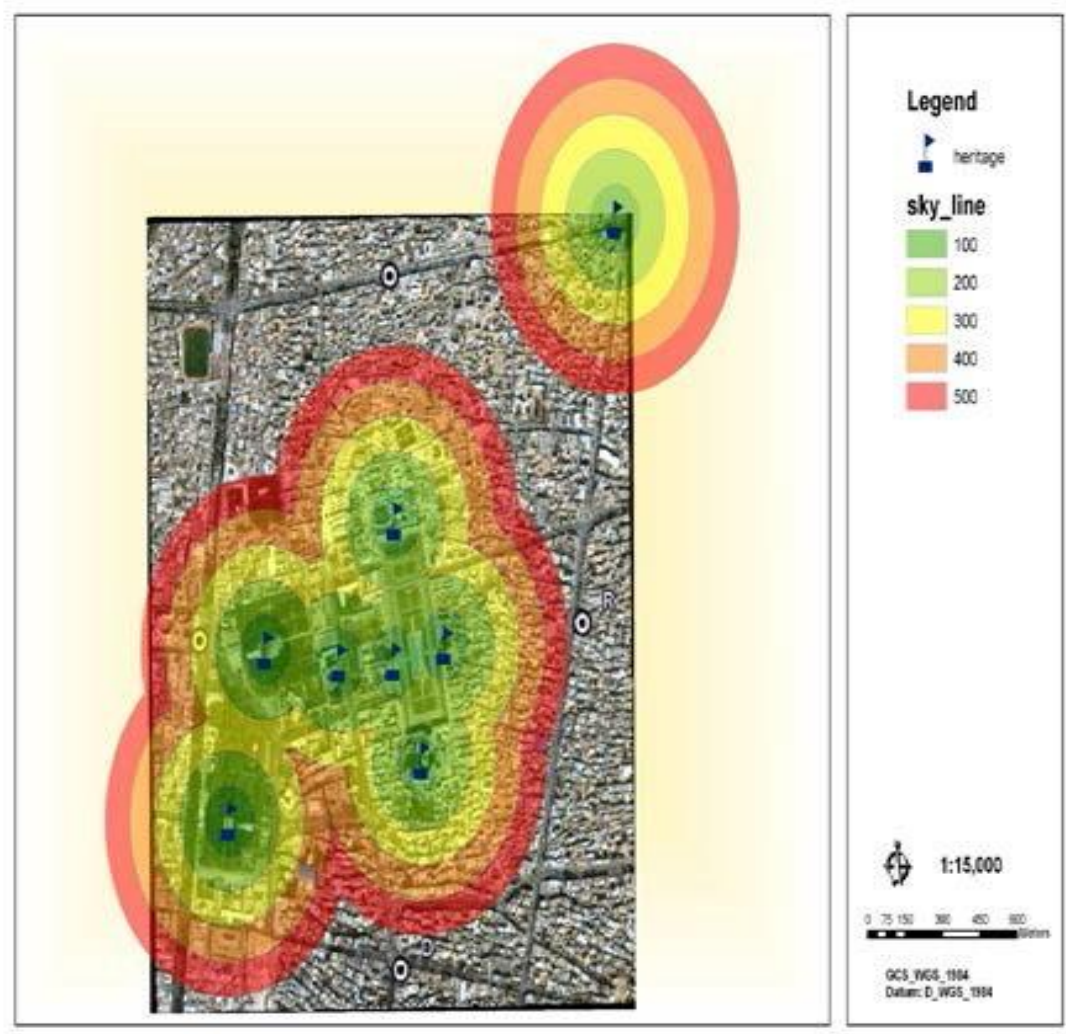

Figure 5. Buffer zoon from major monuments.

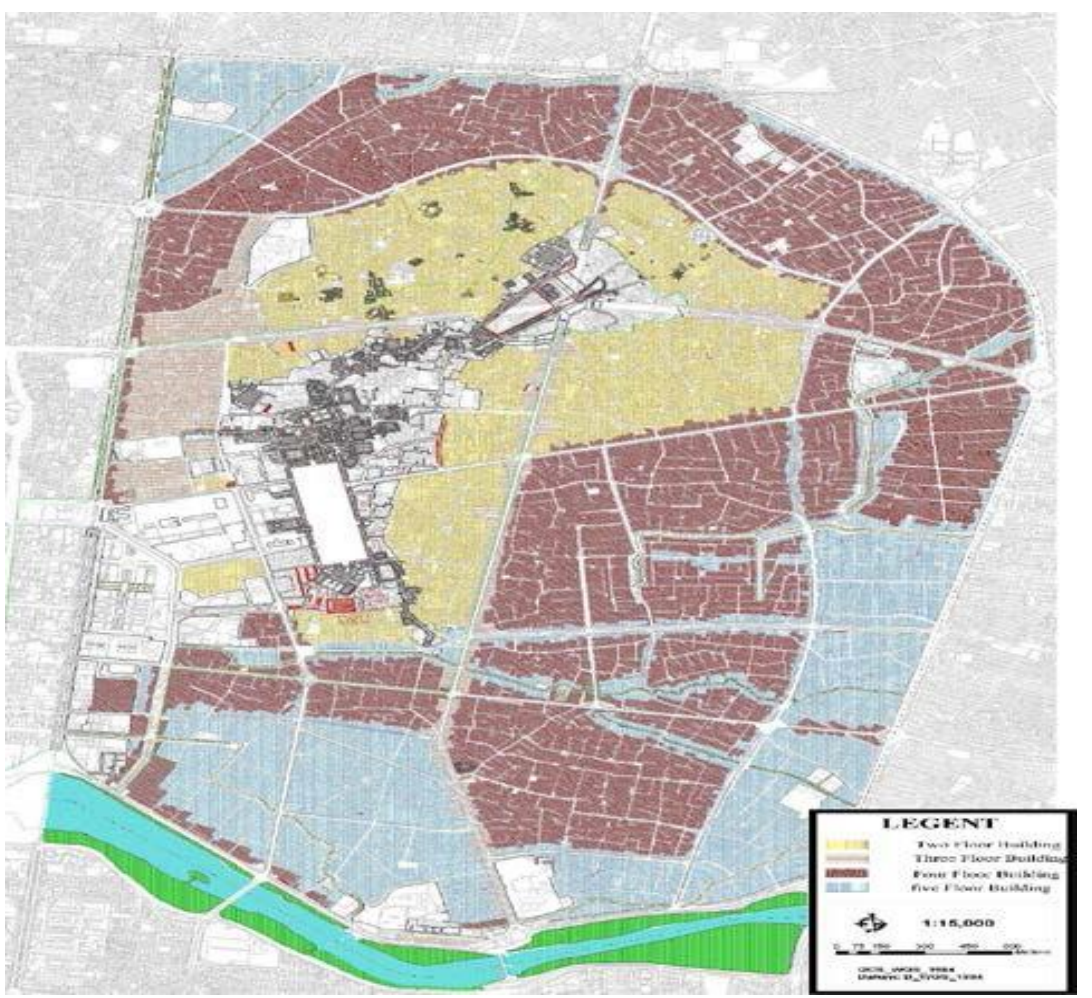

Figure 6. Height of the building in city core. 


\section{REFERENCES}

Adamec LW (2009). Historical dictionary of Islam. Vol. 95. Scarecrow Pr.

Alavi N (2012). LAND USE AND LAND COVER CHANGE DETECTION IN ISFAHAN, IRAN USING REMOTE SENSING TECHNIQUES, in Master of Science in Geography. University of Ottawa: Ottawa.

Asgharpour MJ (1999). Multiple criteria decision making. Tehran: Tehran University Press.

Assari A et al. (2015). P30: Investigation of Sustainability in Road Transportation: A Case Study in Isfahan, Iran. Neurosci. J. Shefaye Khatam 2(4):80-80.

Assari A, Assari E (2012). Urban spirit and heritage conservation problems: case study Isfahan city in Iran. J. Am. Sci. 8(1):202-209.

Assari A, Birashk B, Nik MM, Naghdbishi R (2016). Impact of built environment on mental health: review of Tehran City in Iran. 8(26):8187.

Assari A, Mahesh T (2011). Demographic comparative in heritage texture of Isfahan City. J. Geography and Regional Plann. 4(8):463470.

Assari A, Mahesh T (2011). Urbanization Process in Iranian Cities. Asian J. Dev. Matters 5(1):151-154.

Assari A, Mahesh T, Assari E (2012). Conservation of historic urban core in traditional Islamic culture: case study of Isfahan city. Indian J. Sci. Technol. 5(1):1969-1976.

Assari A, Mahesh T, Assari E (2012). Role of public participation in sustainability of historical city: usage of TOPSIS method. Indian J. Sci. Technol. 5(3):2289-2294

Ball S, Korukoğlu S (2009). OPERATING SYSTEM SELECTION USING FUZZY AHP AND TOPSIS METHODS. Math. Comput. Applications 14(2):119-130.

Batisani N, Yarnal B (2011). Elasticity of capital-land substitution in housing construction, Gaborone, Botswana: Implications for smart growth policy and affordable housing. Landscape Urban Plann. 99(2):77-82.

Benitez JM, Martin JC, Roman C (2007). Using fuzzy number for measuring quality of service in the hotel industry, Tour. Manage. 28(2):544-555.

Bhatta B, Saraswati S, Bandyopadhyay D (2010). Urban sprawl measurement from remote sensing data. Appl. Geogr. 30(4):731-740.

Brueckner JK (2000). Urban sprawl: diagnosis and remedies. Int. Regional Sci. Rev. 23(2):160-171.

Cervero R (2004). Transit-oriented development in the United States: Experiences, challenges, and prospects. Vol. 102. Transportation Research Board.

Cowan R, Hall PG (2005). The Dictionary of Urbanism. Streetwise Press.

CSIR (2000). GUIDELINES FOR HUMAN SETTLEMENT PLANNING AND DESIGN. Vol. (2000). Pretoria: CSIR Building and Construction Technology. 280.

Danielsen KA, Lang RE, Fulton W (1999). Retracting suburbia: smart growth andthe future of housing. Housing Policy Debate. Housing Policy Debate 10:513-540.

de Sousa Vale D (2008). Sustainable urban form, accessibility and travel: the relationship between polycentric urban development and commuting in Lisbon, in school of Architecture, Planning and landscape. Newcastle University: Newcastle.

Ehlers E (1991). Cities. iv. Modern urbanization and modernization in Persia. Encyclopaedia Iranica, 5(6):623-629.

Ehlers E, Floor W (1993). Urban change in Iran, 1920-1941. Iranian Stud. 26(3-4):251-275.

Fanni Z (2006). Cities and urbanization in Iran after the Islamic revolution. elsevier science direct: Cities, 23:407-411.

Farris JT (2001). The barriers to using urban infill development to achieve smart growth. Housing Policy Debate 12(1).

Farzanmanesha R, Naeenib AG, Abdullaha AM (2010). Parking site selection management using Fuzzy logic and Multi Criteria Decision Making. Environment Asia.

Ferdowsian F (2001). Modern and Traditional Urban Design Concepts and Principles in Iran. University of Stuttgart, Institute of Urban Planning.
Gabriel SA, Faria JA, Moglen GE (2006). A multiobjective optimization approach to smart growth in land development. Socio-Economic Planning Sci. 40(3):212-248

Haase D, Nuissl H (2007). Does urban sprawl drive changes in the water balance and policy?: The case of Leipzig (Germany) 18702003. Landscape and Urban Planning 80(1):1-13.

Hasse JE (2004). A geospatial approach to measuring new development tracts for characteristics of sprawl. Landscape J. 23:52 67.

Hooshangi F (2000). Isfahan, city of paradise: A study of Safavid urban pattern anda symbolic interpretation of the Chahar-Bagh gardens, in Master's thesis. Carleton Universityfrom ProQuest Dissertations and Theses Database.

Hwang CL, Yoon K (1981). Multiple attributes decision making methods and applications. Berlin, Springel.

Iranian Statistic Center (2009). Census data: Tehran, Iran

Jacobs J (1961). The Death and Life of Great American Cities. New York: Random House.

Jamal Mohammadi AZ, Omid Mobaraki (2012). Urban sprawl pattern and effective factors on them: The case of Urmia city, Iran. J. Urban Regional Anal. 4(1):77-89.

Kemp RL (2005). The inner city: a handbook for renewal. 2001 , McFarland \& company inc publishers: North Carolina.

Kheirabadi M (2000). Iranian cities: formation and development. Syracuse Univ Pr.

Leichenko RM, Solecki WD (2005). Exporting the American dream. The globalization of suburban consumption landscapes. Regional Stud. 39:241-253.

Miller JS, Hoel LA (2002). The "smart growth" debate: best practices for urban transportation planning. Socio-Econ. Plann. Sci. 36(1):1-24.

Ministry of Housing and Urban Development (2008). Iranian cities and their spatial distribution in different periods: Tehran, Iran.

Mirmoghtadaee M (2010). Demands and Feasibilities of Infill Development in Iranian Urban Areas-the Case Study of Tehran. in W101 - Special Track 18th CIB World Building Congress. Salford, UK.

Moghimi L, Assari A (2016). Redefinition of Pedestrian Route-Finding Networks as a Tool to Return Vitality and Responsiveness to Yazd Khan Plaza. Curr. World Environ. 11(2):378-387.

Mokhtari Malekabadi R (2010). The analysis of parking land use planning in Isfahan city using applied models of regional planning. urban- regional studies and research (university of Isfahan), pp. 115 134.

Price M, Benton-Short $L$ (2008). Migrants to the metropolis: the rise of immigrant gateway cities. Syracuse University Press.

Saeed Zanganeh Shahraki DS (2011). Pere Serra, Sirio Modugno,Faranak Seifolddini,Ahmad Pourahmad, Urban sprawl pattern and land-use change detection in Yazd, Iran. Habitat International, 35(2011):521-528.

Saoud R (2002). Introduction to the Islamic City. Manchester: Foundation for Science Technology and Civilisation.

Smart Growth (2003). Case study: Western Reverside County. Southern California Association of Governments: California. Smart Growth Online 2012 [cited 201215 april]; Available from: http://www.smartgrowth.org/about/default.asp.

Soffianian A, et al. (2010). Mapping and Analyzing Urban Expansion Using Remotely Sensed Imagery in Isfahan, Iran. World Appl. Sci. J. 9(12):1370-1378.

Stalker P (2000). Handbook of World. New York: Oxford University Press.

Statistical-Centre-of-Iran (2006). National Census of 2006 and 1996,1986. cencuse book: Tehran,Iran.

Underwooda JG, Francis J, Gerber LR (2011). Incorporating biodiversity conservation and recreational wildlife values into smart growth land use planning. Landscape and Urban Planning pp. 136-143.

Vadiati N, Kashkooli A (2011). Environmental Sustainability of Newly Developed City Squares in Historic Cities: Case Study of IsfahanIran. Procedia Eng. 21:829-837. 